\title{
Impact of Corporate Governance on Corporate Value for Companies Listed at the Nairobi Securities Exchange
}

\author{
David Onguka $^{1}$, Cyrus Iraya $^{2} \&$ Winnie Nyamute ${ }^{2}$ \\ ${ }^{1} \mathrm{PhD}$ Student, Department of Finance and Accounting, School of Business, University of Nairobi, Kenya \\ ${ }^{2}$ Lecturers, Department of Finance and Accounting, School of Business, University of Nairobi, Kenya \\ Correspondence: David Onguka, University of Nairobi; School of Business; Department of Finance and \\ Accounts, P.O Box 58823, 00200, Nairobi, Kenya. Tel. 254-713-542-259. E-mail: davidonguka@ gmail.com
}

Received: September 12, 2020

Accepted: November 12, 2020

Online Published: November 25, 2020

doi:10.5539/ijef.v12n12p70

URL: https://doi.org/10.5539/ijef.v12n12p70

\begin{abstract}
The study objective is to establish the impact of corporate governance on corporate value of firms listed at the Nairobi Securities Exchange. From time to time, capital market authorities have issued guidelines and regulations for good corporate governance in different areas in order to ensure solid and sound management of listed companies and to align the interests of all stakeholders thus ensuring the firm's sustainability and optimization of the company's value. Despite these policies, cases of failure and corporate underperformance caused by unsound corporate governance continue to increase in frequency and magnitude. The paper tested the hypothesis that there is no significant influence of corporate governance on corporate value. Corporate governance measurements variables were board independence, board size, board composition and board gender diversity while corporate value was measured by Tobin Q. Data was obtained from past audited financial statements of firms quoted at the NSE. The study used census survey for sixty-four listed companies. The analysis covered a five years period between 2013 and 2017. The study applied agency theory as the anchoring theory. Descriptive statistics and diagnostic tests were conducted on the data thereafter inferential statistics namely correlations analysis and regression analysis were used to test the hypothesis. When the data on the study variables was subjected to descriptive statistics, the results showed a significant relationship between the variables. The panel data approach was considered more appropriate because the sample data contained both cross-sectional and time-series data. The study revealed positive and significant relationship between corporate governance and corporate value.
\end{abstract}

Keywords: corporate governance, agency theory, corporate value

\section{Introduction}

The subject of corporate governance has stimulated a great deal of empirical investigation in finance and economics since the groundbreaking seminal publication by Smith (1776)'s on the investigation of the characteristic and source of wealth of nations. This study meant at assess the cause of company's underperformance and failures which continue to rise in frequency and magnitude at NSE despite the various measures that have been established by regulatory authorities such as Central Bank and Capital Market Authority (CMA). Although the improvement and implementation of corporate governance principles and regulations have contributed to improve corporate performance significantly, there are still increasing cases of failures and underperformance (Dominic \& Memba, 2015).

Corporations are established to create value through identifying market needs, creating a system and process of meeting these needs, identifying resources needed, obtaining funds to finance the acquisition of these resources either through shareholders and/or financial institutions and managing and directing these resources to meet the identified needs effectively and efficiently thereby generating value in the process. Corporate governance which involve directing, managing systems, resources and people is therefore key in value creation. Studies have shown that prudent corporate governance rules application enhances investors' confidence regarding the company's profitability (Alqisie, 2014).

We have recently experienced Uchumi and Nakummat Supermarkets being put under management by CMA in 2015, as well as the insistent losses at Mumias Sugar and Kenya Airways despite constant bails out by the 
Kenyan Government in addition to other listed entities. Several studies have attributed this problem to ineffective corporate governance and financial difficulties (Peters \& Bagshaw, 2014). Recent studies postulated that this reflects ingrained corporate governance inadequacies like board oversight complacency, absence of strategic forethought by the firms' management and poor corporate governance (Vincent et al., 2015; and Opiyo, 2013).

Dor et al. (2011) defined corporate governance as the broad principle in which businesses are led and directed. It can be said to be a power relationship between shareholders, top management and directors in determining the company's performance and direction. It is therefore an the internal process of managing and controlling the corporation's business and activities through people, processes and systems to realize the shareholders goals and those of other stakeholders (Solomon et al., 2013).

Several corporate failures and underperformance have been attributed to weakness in corporate governance's negative impact on firm performance. Every organization's success story in various industrial sectors has been attributed to corporate governance adherence (Haque \& Arun, 2016). Any corporate governance slack adversely affects the performance and possibly leads to the collapse of even a huge corporations. Poor internal controls, superior and restrictive systems weakness, unsound practices of corporate governance, and conflicting interest are all factors in the history of a poor management system that leads to poor performance (Calomiris \& Carlson, 2016). Other studies have documented an inverse link between firm performance and corporate governance (Robbins \& Judge, 2017). While some found no relationship (Ali, 2018). This led to a question of whether corporate governance positively impacts corporate value.

Corporate governance measurement has taken several approaches. Corporate boards are responsible for major decisions in an organization. For example, resolutions such as change of by-laws, shares issues, dividends declaration among others. This partly explains why corporate governance discussions tend to focus on the boards. Research has not established a common set of elements to be used as measuring variables for corporate governance. Different researchers use different boards of directors' attributes as a proxy to measure corporate governance and this creates inconsistency (Carty \& Weiss, 2012; and Proudfoot et al., 2016). Such attributes include board size, female representation on boards (gender), CEO duality, board independence, board composition, and more.

Value can be defined as the attainment of predetermined targets, objectives, and goals within a given timeframe (Eyenubo, 2013). Corporate Value realized is therefore an assessment of a firm's realization of its economic objectives and this has long been a subject of concern in managerial research. We best look at value in two ways: the end results and the means of getting the results. Anderson, Becker, and Campbell (2014) notes that corporate value or performance enables one to distinguish the outcome of organizational activities.

A perennial question that has inundated previous corporate governance and value studies have to do with the choice of recognized measures of value. Which measure is suitable for assessing company value? Thus, the conceptualization of value remains a contentious finance issue mainly because of its multi-dimensional explanations. Research into company value is arise from strategic management and organization theory (Stiglbeuer, 2011). Shareholders thus require assurance on profitability, growth, viability, investment returns and the firm's continuous financial sustainability (Lishenga, 2012). Corporate governance affects entity's value by reducing insider expropriation and improving the expected cash flow which would be distributed to shareholders (Ayako et al., 2015). Compared to market-based measures, accounting-based measures are backward-looking. Corporate value measures how efficient and effective management is in employing company resources to generate corporate value (Kiruri, 2013). In this respect, Tobin's Q can be said to be a combination of historical and futuristic. It involves the summation of the market value of equity and book value of debt.

Globally, security exchanges play a fundamental role in corporate regulations measures aimed at optimizing corporate value. This underscores the need for sober corporate governance in operation, financing, and investing activities. Capital markets are considered efficient and critical tools for the development of the economy (CMA, 2019). The Nairobi Security Exchange (NSE) was set up by the London Stock Exchange in 1920 and was incorporated locally in 1954 under the Society Act (Vincent et al., 2015). Its mandate is to promote, develop, support, and discharge all the functions of the security market. It plays the role of capital mobilization, creating investment opportunities as well as serving as the barometer for the health of the country's economy. The NSE is the regulator responsible with corporate governance guidelines compliance. The NSE aims at eliminating the deficiencies documented by past studies, which were aimed at ensuring operative corporate governance for ideal firm value.

Although the NSE has achieved most of its goals, many NSE-listed companies face control and fiscal challenges 
because of distributed structures of ownership arising from public floatation of shares, increase in agency costs and leverage levels as wells as failures in corporate governance due to insufficient supervision (Kiruri, 2013). The bourse plays a key part in the Kenyan economic development as it gives publicly traded firms access to long-term funds by issuing debt and stocks to the public, which precipitates ownership and capital structures respectively.

\subsection{Research Problem}

The importance of corporations adopting corporate governance best practices cannot be overemphasized since global best practices demonstrate a strong connection between good corporate governance and firm profitability. Corporate governance is a key concept that has been linked to a corporate value performance analysis by numerous studies in the past. Agency theory as well as other mechanisms of corporate governance indicate that firm performance is improved by sound corporate governance (Haque \& Arun 2016). Poor corporate governance has proven in part to be a major impediment to improving the corporate value of firms besides not being able to attract capital in an environment with ever-increasing capital mobility.

In Kenya, cases of underperformance and corporate failures continue to increase in magnitude and frequency despite attempts by regulatory authorities to strengthen financial discipline and corporate governance through the implementation of improved governance principles and financial discipline through regular reporting and oversight. Corporate governance is usually discussed in the perspective of state ownership and private ownership of companies where there is mismanagement, corruption and government subsidies on failing publicly traded entities like Kenya Airways, Mumias Sugar among others have been the defining features. Cement maker ARM and fashions retailer Deacons (EA) were put under administration in 2017 due to too high debt and excess losses. Several efforts have instituted to address corporate governance challenges in the country through privatization policy by the Kenyan capital markets authority. The performance trend of listed firms at the NSE has not been impressive in the last decade. NSE index performance has been on a downwards trend for the last 10 years and touched its lowest in March 2019 (CBK, 2019). The problem seems to arise from lack of clarity on the reason for increasing underperformance and failures even with improvements through new acts, better laws, and stronger regulations, being put in place to reduce or stop it. The research objective is therefore to determine the effect of corporate governance on the corporate value of NSE listed firms

\subsection{Literature Review}

\subsubsection{Agency Theory}

Jensen and Meckling (1976) advanced this theory and contended that ownership and control separation generates an agency problem where the management runs the company to satisfy their interest and not necessarily that of the owners. Stiglbauer (2011) refers to the theory as a neoclassical economic theory which is generally the foundation for any corporate governance discussion. According to Morrison and Jenson (2013) when there is asymmetric information, the agents will possibly undertake a decision not in tandem principals' goals.

According to Anderson, Becker, and Campbell (2014) the agency theory is grounded on the belief of self-interest regarding agents' trying to maximize their private financial wealth. Conflicts of interest between the agent and principal in relation to desires and goals as well as the appetites for high risk and debt leads to agency's costs (Alqisie, 2014). Agency costs comprise structuring costs, monitoring, and bonding various contracts between agents who have conflicts of interest, as well as the residual loss suffered when full enforcement costs outweigh the benefits (Wagana \& Karanja, 2015). This theory is based on the agency relationship which subsists in the corporate environment where the agents (management) are held in trust to work in the principals (shareholders) best interests.

Critics of the theory point out that it focuses on divergent relationships alone thereby overlooking the convergence of relationships between various actors and their inter-dependencies (Hasan \& Butt, 2009). These actors are likely to be unique and have symbiotic relationships that may not be easily mapped to such divergent stand of the theory. Not all agents are opportunistic and self-centered as there are some who would act as true captain of the ship if the compensation and reward are worked out to their satisfaction.

\subsubsection{Corporate Governance and Corporate Value}

Dominic and Memba (2015) assessed the influence of debts on profitability of NSE quoted banking entities. A longitudinal research design was utilized in gathering information. In analyzing the information, the SPSS was employed and inferential statistical tools among them regression and correlation were adopted. The research affirmed the adverse effects on firm performance because of debt even if it was not notable statistically as calculated by ROA ( $\mathrm{B}=-.442 ; \mathrm{PV}=0.242>0.05)$. When a firm is well-governed, debts can be optimized and to 
attain their goals and objective of achieving high performance. So, there is a need to incorporate corporate governance and control in the mix to maximize on entity performance. The current study considered corporate governance as the core determinant of corporate value to address the performance optimization objective.

Lekaram (2014) studied corporate regulations with the financial performance of publicly trading manufacturing entities at NSE. The author adopted a descriptive approach and used a panel regression framework for data analysis. The finding was that the firm performance in relation to ROA and ROE was indirectly related to firms' board size. The manufacturing segment at NSE had been under-researched in prior studies. However, considering a wider population like all listed firms at the NSE would widen the study's context. Given the prominence of company governance to the overall profitability of a firm, there is a need to consider its various attributes of board independence, size, composition and board gender diversity in optimizing shareholders value.

Opiyo (2013) investigated whether corporate governance influenced insider trading - this involved entities trading at NSE. The research applied a descriptive survey. The author documented that corporate governance affects insider trading. This was attributed to the fact that board size and structure, ownership by banks, and other institutions, and ownership concentration provided a strong monitoring mechanism. The research did not consider the effect on corporate value growth. The study documented a non-significant link between corporate governance and profitability thereby failing to confirm agency theory prediction of a positive relationship.

Peters and Bagshaw (2014) reviewed corporate governance (CG) tools and the monetary value of Nigerian quoted companies. They used a judgmental sampling approach choosing 33 companies out of over 200 quoted companies at the Nigerian Securities Exchange (NSE). Results indicated that the adopted corporate governance mechanisms had an impact on company's decisions to reveal information about their corporate governance online. The research adopted the OLS method of analysis. This shows that the monitoring mechanism adopted by capital market authority is crucial to companies' compliance. The choice of OLS as the way of analysing data failed to address the aims of the type of study in question, therefore the present research analysed and considered the use of longitudinal design using panel data for the companies quoted at NSE.

The empirical analysis of relationships on corporate governance and company value has not documented an uncontested causal linkage among the variables. Majority of the existing studies document methodological, contextual as well as theoretical gaps. Studies concerning corporate governance and corporate performance have generated inconsistent and contradictory results. Some studies have documented positive relationships while others have reported either negative or no relationships.

\subsection{The Conceptual Framework}

A study's conceptual model shows the interlinkage of the identified research variables. The relationship captures the hypothesis indicating the link between the explanatory variable (corporate governance) and the response variable (corporate value). Corporate governance indicators included board independence, size, composition and gender diversity which were expected to have significant influence on corporate value proxied by the Tobin Q. This proposition, supported by the Agency theory, is shown as part of the study's hypothesis under figure 1 . The position has been explored by several authors who have explored the interrelationship between corporate governance and corporate value with mixed and inconclusive results.

Independent Variable

Dependent Variable

\begin{tabular}{|l|l|}
\hline Corporate Governance \\
-Board Independence \\
-Board Size \\
-Board Composition \\
-Board Gender Diversitv
\end{tabular}

Figure 1. The conceptual model

Source: Author (2020).

Agency theory and the relationship conceptualized by the model shows that corporate governance may positively and significantly impacted corporate value and this forms the hypothesis of the study.

\section{Research Methodology}

The research methodology refers to a roadmap that explains how data was gathered, analysed, and interpreted to realize the study's objectives (Rose, 2017). The strides with perspectives sought in undertaking the proposed 
research study design, population, data collection, diagnostic tests, operationalization, and data analysis

\subsection{Research Design}

Research design denotes the structure and plan of investigating a situation designed in such a way that research can obtain answers to the research questions (Kothari, 2004). It's a study's outline on a phenomenon that allows a research to get answers to research questions (Carter \& Greer, 2013). The study adopted a descriptive longitudinal design through the use of panel data. The panel data technique was deemed suitable as the study's data entailed both time series and cross sectional components (Mang'unyi, 2011). This was applied across 58 companies for a five years period resulting to 290 data points.

\subsection{Population and Sampling}

A population refers to a whole collection of persons, objects or events with collective attributes that correspond to a certain description (Cooper \& Schindler, 2008). As of December 31, 2017, only 64 companies were listed at the NSE hence the 64 firms formed the study's population. However, our data of about 64 firms was cleaned, leaving a lesser number of 58 firms because of both the loss of some firms due to company changes like going private, new listings and loss of some years of observations for the remaining firms due to unavailability or poor quality of data on some years (Bloom \& Van Reena, 2001). The 58 firms with full data forms over $90 \%$ of the sample. The publicly traded firms were preferred because they have a distinct structure and a legal operating mandate and gave elaborate interrelationship among the research variables which provided a basis for objective assessment of market value and performance.

\subsection{Data Collection}

Gujarati (2003) defines data collection as the systematic and precise collection of information about a research problem using various methods among the interviews, focused group discussions, participant observations, case histories and narratives. This research employed quantitative secondary data which was collected for a five-year period through data collection form. The data was obtained from existing financial statements of the entities quoted at NSE. Additional, secondary data was obtained from companies' websites, accounting reports, and other records filed with NSE. Where necessary data were not obtained, the same was requested directly from the company's management.

\subsection{Operationalization and Measurement of Research Variables}

Operationalization is a procedure that assigns numbers, numerals, and other symbols to examine variables. According to Beck and Wiersem (2013), operationalization is a clear description of variables in a measureable manner. Corporate Governance indicators were board independence (the ratio of independent board members), board size (total board members), board composition (the ratio of Executive directors in the board), and gender diversity (the ratio of female directors in the board). This was consistent with measures used by Proudfoot (2016). Equal weighted composite of the four sub variables form the measure for Corporate Governance. The corporate value was measured by Tobin Q.

Table 1. Variables operationalization and measurement

\begin{tabular}{|c|c|c|c|c|}
\hline Variables & Nature & Indicator & Measurements & Supported \\
\hline Corporate Value & Dependent variables & Tobin Q & $\mathrm{TQ}=\frac{M V E+B V D}{B V A}$ & Okiro (2014) \\
\hline \multirow{6}{*}{ Corporate Governance } & \multirow{6}{*}{ Independent variables } & Board Gender Diversity & $\frac{\% \text { Female Directors }}{\text { Total Directors }}$ & Velte (2017) \\
\hline & & Board Size & Log no. of Directors & Proudfoot (2016). \\
\hline & & \multirow[t]{2}{*}{ Board Composition } & $\frac{\% \text { Executive Directors. }}{\text { Total Directors }}$ & Alqisie (2014) \\
\hline & & & $\%$ Non - Ex. Directors & \multirow[b]{2}{*}{ Calomiris and Carlson (2016) } \\
\hline & & Board Independence & Total Directors & \\
\hline & & Corporate Gov. Composite & $1 / 4(B I+B S+B C+B G D)$ & Haque and Arun (2016) \\
\hline
\end{tabular}

Source: Researcher (2020).

\subsection{Diagnostic Tests}

Several diagnostic tests have been used to justify the validity of regression results to assess the appropriateness of the regression model. This was done on the supposition that it would be impossible to draw reliable and accurate inferences regarding reality of the population from which the sample was taken is invalid (Creswell, 2013). The classical linear regression model (CLRM) is centered on several assumptions such as linearity, little 
or no multicollinearity, multivariate normality, no autocorrelation and homoscedasticity.

Regression analysis requires the existence of little or zero serial correlation (autocorrelation) in a data set. Autocorrelation arises in situation as a results of non-independent predicted residuals from one another. Panel data autocorrelation was assessed using the Durbin-Watson (DW) statistics $(1.5<\mathrm{d}<2.5)$. Linearity between the dependent and independent variables was assessed using the ANOVA linearity test where non-linearity was deemed significant when the calculated $\mathrm{F}$ statistics value for the non-linear indicator was less than 0.05 . VIF (tolerance) test was used to assess the presence of multicollinearity where a VIF value of not more than 10 and tolerance value not far from 1 indicated existence of multicollinearity. The Levene's statistics assessed the null hypothesis on whether the population variances were equal (referred to homoscedasticity or homogeneity of variance). Regression analysis further requires that the study data be multidimensional normal. Thus, normality was assessed using the Kolmogorov-Smirnov test, and the more robust normality test, the Shapiro-Wilk test.

\subsection{Data Analysis}

Carty and Weiss (2012) indicates that data analysis is the use of reasoning to apprehend the gathered data to generate consistent patterns and summarize the pertinent details revealed during the investigation. Multiple regression analysis was employed for testing the strength and direction of the variables. The Statistical Program for social sciences (SPSS) version 26 was adopted for analysis of descriptive and inferential statistics. The regression analysis was in line with the analysis adopted in previous studies to test the impact of corporate governance on company value (Okiro, 2014; and Mang'unyi, 2011).

A multivariate regression model was adopted to establish the relationship between corporate governance and the firm's value. The hypothesis $\left(\mathrm{H}_{1}\right)$ testing model was as follows:

$$
C V_{i t}=\beta_{0}+\beta_{1} B I_{i t}+\beta_{2} B S_{i t}+\beta_{3} B C_{i t}+\beta_{4} B G D_{i t}+\varepsilon_{i t}
$$

Where CV represents Corporate Value (measured by Tobin Q), $\beta_{0}$ is the intercept or Constant, $\beta_{1^{-}} \beta_{4}$ are regression coefficient, $\varepsilon$ is a random error term, i represents the cross sectional (firm) component and $t$ represent the time series (years) component. BI, BS, BC and BGD are board independence, board size, board composition and board gender diversity respectively.

\section{Results}

\subsection{Statistical Assumptions Test}

The statistical assumptions above were tested and results were summarized under table 2 . Where the results agreed with the regression assumptions, the resultant data was further subjected to other statistical analysis, including hypothesis testing.

Table 2. Statistical assumptions test results

\begin{tabular}{llccccc}
\hline & Assumption (Test) & $\begin{array}{c}\text { Normality } \\
\text { (Shapiro Wilk) }\end{array}$ & $\begin{array}{c}\text { Linearity } \\
\text { (ANOVA) }\end{array}$ & $\begin{array}{c}\text { Independence } \\
\text { (Durbin Watson) }\end{array}$ & $\begin{array}{c}\text { Homogeneity } \\
\text { (Levene) }\end{array}$ & $\begin{array}{c}\text { Collinearity } \\
\text { (Tolerance) }\end{array}$ \\
\hline Variable & Attribute & $\mathrm{P}>0.05$ & $\mathrm{P}>0.05$ & $1.5<\mathrm{d}<2.5$ & $\mathrm{P}>0.05$ & VIF 10 Max \\
& Board Independence & 0.4 & 0.27 & 1.765 & 0.845 & 1.165 \\
Corporate & Board Size & 0.324 & 0.76 & 1.765 & 0.619 & 1.032 \\
Governance & Board Composition & 0.24 & 0.406 & 1.765 & 0.365 & 1.231 \\
& Board gender diversity & 0.26 & 0.34 & 1.765 & 0.418 & 1.049 \\
\hline
\end{tabular}

Source: Research data.

The Shapiro-Wilk test was used for normality testing and to detect any deviation from normality because of kurtosis, skewness or both. The findings indicated that all P-values ( $p>0.05)$ were greater than 0.05 which confirmed the variables normality. The normality assumption indicates that the mean sample distribution is normal. Linearity was assessed through the ANOVA linearity test, which calculates both the nonlinear and linear components of a variables pair, with linearity being significant when the significance value $\mathrm{F}$ for the linear component was greater than 0.05. The calculated values for the ANOVA test were all above 0.05, which confirms the linear relationships (constant slope) among the research variables. Further, the study tested for serial correlation, which means that the observations are independent through the use of the Durbin-Watson (DW) statistic whose threshold values ranges between 1.5 and 2.5 . The test results were 1,765 , which confirms the absence of autocorrelation. The Levene's homogeneity test was used for heteroscedasticity testing. All the calculated $\mathrm{P}$ values $(0.845,0.619,0.365 \& 0.41>0.05)$ which confirmed homogeneity. Further, multicollinearity was assessed through the calculation of Variance Inflation Factors (VIFs) and their reciprocal (Tolerance). 
Multicollinearity arises when the predictor variables are strongly correlated, which makes it hard to ascertain the accurate influence of each of the predictors in relation to the response variable. The assumption of multicollinearity has a maximum VIF cut off point of 10 (Sekaran \& Bougie, 2009). The calculated tolerance for all variables was less than 1, hence its reciprocal (VIF) ranged between two and one, which was within the recommended threshold.

\subsection{Descriptive Statistics}

Descriptive statistical tools were used to describe the basic data features by presenting basic summaries of the population/sample and the indicators used. Sekaran and Bougie (2009) claim that descriptive analysis, alongside simple graphical analysis, forms the foundation of any quantitative data analysis. The descriptive statistics refer to the measurement of data in terms of the minimum, maximum, mean, standard error of estimates. It also includes measures of symmetry - skewness and flatness or sharpness of data - kurtosis.

The study's descriptive statistics analysis on the variables are shown in Table 3 below

Table 3. Corporate governance descriptive statistics

\begin{tabular}{ccccccc}
\hline Variables & Min & Max & Mean & Standard Deviation & Skewness & Kurtosis \\
\hline Board Independence & 0.55154 & 0.85967 & 0.615542 & 0.1384523 & -0.613 & -0.131 \\
Board Size & 0.5485 & 1.1855 & 0.84286 & 0.175675 & -1.147 & 0.787 \\
Board Composition & 0.3256 & 0.6413 & 0.555125 & 0.153591 & -0.376 & -0.728 \\
Board Gender Diversity & 0.01058 & 0.62033 & 0.253865 & 0.0871868 & -0.3 & 1.441 \\
\hline
\end{tabular}

Source: Research Data.

From the data received from 58 listed firms for five years forming 290 data points (Table 3), the findings indicates that listed firms in Kenya had independent directors constituting $61.5 \%$ of the board size, with a maximum of $85 \%$ and a minimum of $55 \%$ which were spread on either side of the mean by $13.8 \%$. The findings further indicated that the average board size of the firms was 7 board members (antilog of .8428), a maximum of 16 (antilog of 1.1855) directors and a minimum of 4 (antilog of .5485) directors, which deviate by 2 (antilog of .1757) directors on both sides of the mean. On average Board Composition of executives constituting 55\% of the Board, with a maximum of $64 \%$ and a minimum of $32 \%$ which were spread on either side of the mean by $15 \%$. The findings also indicate that listed firms in Kenya had female directors constituted $25.4 \%$ of the board's size, with a maximum of $62 \%$ and a minimum of $10 \%$ which were spread on either side of the mean by $9 \%$.

\subsection{Test of Correlation Analysis}

Examining the correlation coefficients helps on whether to accept or reject the null hypothesis that no correlation exists between two explanatory variables. The association between two variables ranges between -1 and +1 . A +1 correlation indicates the existence of a perfect positive link among the variables and therefore indication of the multicollinearity problem (Sekaran \& Bougie, 2009). The correlations between Corporate Value and corporate governance indicators was evaluated using Pearson correlation analysis. The results were presented in Table 4 below.

Table 4 documents the correlation analysis results

Table 4. Correlation between corporate governance and corporate value

\begin{tabular}{lccccc}
\hline & Board Independence & Board Size & Board Composition & Board Gender Diversity & Corporate Governance \\
\hline Corporate Value & $.150^{*}$ & -0.062 & $-.321^{* *}$ & -0.055 & -0.079 \\
\hline
\end{tabular}

** Correlation is significant at the 0.01 level and * at the 0.05 level (2-tailed).

Source: Research Data.

Table 4 indicates the results of the correlation analysis between Corporate Governance and Corporate Value. The results indicate a statistically significant and positive correlation existed between Board Independence and Corporate Value $(\mathrm{r}=.15, \mathrm{p}<0.05)$. Corporate value worsened with an increase in board size as well as with Board Gender Diversity. Board Composition and Corporate Value had a negative significant relationship ( $\mathrm{r}=-.321$, $\mathrm{p}<0.01)$ meaning that as the number of executive directors increases, corporate value decreases.

\subsection{Effect of Corporate Governance on Corporate Value}

This section assessed whether Corporate Governance affected Value of corporations quoted at the NSE. The attributes of Corporate Governance were board independence, board size, board composition, and board gender 
diversity. Corporate Value was proxied by Tobin Q. Information retrieved from published annual published reports of the NSE quoted corporations formed the basis of the analysis. The study's null hypotheses was as follows:

\section{$\mathrm{H}_{1}$ : There is no significant relationship between Corporate Governance and Corporate Value for NSE listed companies}

The test the above hypothesis $\mathbf{H}_{\mathbf{1}}$, four steps were used to undertake a hierarchical multiple regression with the first step entailed regressing the Corporate Value against Board Independence, the second step involve regression Corporate Value against Board Independence and Size, the third step involves regressing Corporate Value against, Board Independence, Size and Composition, the fourth step involves regressing Corporate Value against, Board Independence, Size, Composition, and Gender Diversity. The test of hypothesis was done through a modified multiple regression model as described under data analysis as follows:

$$
C V_{i t}=\beta_{0}+\beta_{1} B I_{i t}+\beta_{2} B S_{i t}+\beta_{3} B C_{i t}+\beta_{4} B G D_{i t}+\varepsilon_{i t}
$$

Table 5 present the regression results

Table 5. Effect of corporate governance on corporate value

\begin{tabular}{|c|c|c|c|c|c|c|c|c|}
\hline Variables & $\beta$ & SE & Std. $\beta$ & $\mathbf{t}$ & $\mathbf{R}$ & $R^{2}$ & $\Delta \mathrm{R}^{2}$ & $\mathbf{F}$ \\
\hline Model 1 & & & & & 0.148 & 0.022 & 0.022 & $6.44^{*}$ \\
\hline Constant & 0.834 & 0.072 & & $11.629^{\star \star}$ & & & & \\
\hline Board Independence & 0.415 & 0.164 & 0.148 & $2.538^{\star}$ & & & & \\
\hline Model 2 & & & & & 0.155 & 0.024 & 0.002 & 0.659 \\
\hline Constant & 0.896 & 0.105 & & $8.564^{\star \star}$ & & & & \\
\hline Board Independence & 0.407 & 0.164 & 0.145 & $2.476^{*}$ & & & & \\
\hline Board Size & -0.105 & 0.129 & -0.047 & -0.812 & & & & \\
\hline Model 3 & & & & & 0.323 & 0.104 & 0.08 & $25.619^{\star \star}$ \\
\hline Constant & 1.893 & 0.221 & & $8.56^{\star \star}$ & & & & \\
\hline Board Independence & 0.088 & 0.17 & 0.031 & 0.517 & & & & \\
\hline Board Size & -0.009 & 0.126 & -0.004 & -0.07 & & & & \\
\hline Board Composition & -1.654 & 0.327 & -0.309 & $-5.062^{\star \star}$ & & & & \\
\hline Model 4 & & & & & 0.345 & 0.119 & 0.014 & $4.668^{\star}$ \\
\hline Constant & 2.112 & 0.242 & & $8.728^{\star \star}$ & & & & \\
\hline Board Independence & 0.09 & 0.169 & 0.032 & 0.531 & & & & \\
\hline Board Size & 0.09 & 0.125 & -0.012 & -0.212 & & & & \\
\hline Board Composition & -1.781 & 0.33 & -0.333 & $-5.397^{\star \star}$ & & & & \\
\hline Board Gender Diversity & -0.549 & 0.254 & -0.123 & $-2.161^{*}$ & & & & \\
\hline
\end{tabular}

Note. ${ }^{*} \mathrm{p}<0.05, * * \mathrm{p}<0.01$.

Dependent Variable - Corporate Value.

Source: Research Findings.

As presented in Table 5 above, a four-stage hierarchical regression was used with Corporate Value as the dependent variable. Board Independent was entered in stage one (Model 1), Board Independence and Board Size were entered in stage two (Model 2), Board independence, size and composition were entered in stage three (Model 3) and in stage four (Model 4), the Board's independence, size, composition, and board gender diversity were entered.

The results showed that Board Independence had a statistically significant effect on Corporate Value $\left(\mathrm{R}^{2}=\right.$ $0.022, \mathrm{p}<0.01)$ but explaining only $2.2 \%$ of the corporate value $\left(\mathrm{R}^{2}=0.022\right)$. The addition of board size did not significantly change the result thus the conclusion that Board Independence and Board Size explains an insignificant amount of $(2.4 \%)$ of Corporate Value $\left(\mathrm{F}=0.659, \mathrm{p}>0.05, \mathrm{R}^{2}=0.024, \Delta \mathrm{R} 2=0.002\right)$ and the relationship became statistically insignificant with this addition. However, the addition of board composition in the third stage made the relationship with Corporate Value significant $\left(F=25.619, P<0.01, R^{2}=0.104, \Delta R^{2}=0.08\right)$ with the increased explanatory power of $10.4 \%$ of the Corporate Value. The addition of Board Gender Diversity did at stage four had a significant impact on the result increasing explanatory power to $11.9 \%$ of Corporate Value $\left(\mathrm{F}=4.668, \mathrm{p}<0.01, \mathrm{R}^{2}=0.119, \Delta \mathrm{R}^{2}=0.14\right)$, the relationship also remained statistically significant.

The results further indicated that the constant had beta coefficient of $(\beta=2.112)$, thus the model's line of best fit, was statistically significant. The beta coefficients of Board Independence, Board Size, Board Composition, and Board Gender Diversity in model 4 were $0.09,0.09,-1.781$, and -0.549 correspondingly. The t value (slope coefficient/standard error) for Board Composition was -5.397 which was statistically significant $(\mathrm{p}<0.01)$. The $\mathrm{t}$ value for Board Gender Diversity was -2.161 which was also statistically significant $(\mathrm{p}<0.05)$. The results also indicate that Corporate Governance significantly predicts Corporate Value. The null hypothesis is therefore rejected. 


\section{Discussion}

The study found that Corporate Governance significantly influences Corporate Value. This implies that corporate governance is a key corporate value driver of corporations quoted at the Nairobi Stock Exchange. Additionally, the result documented that the board independence and size were are significantly related to the company's value. The agency theory indicates that company's agent are likely to pursue self-interests, which affects the company's value. Thus, with a large board, oversight can minimize the risk associated the agency conflicts, while greater board independence also helps to ensure that the agent is closely monitored, which adds to greater investor and stakeholder confidence, which lead to a stronger Tobin's Q. This implies that when the board of directors and Corporations makes better optimal decisions, corporate entities tend to perform better.

The study's findings adds on to the existing empirical and theoretical knowledge on Corporate Governance. Some previous studies have evaluated the interrelationship between Corporate Governance and Corporate Value (Holderness, 2016; M'Ithiria \& Musyoki, 2014; and Okiro, 2014), However, measurement used for Corporate Value were different and different sub-variables of corporate governance were used or the sub-variables were studied separately and not in the same combination, the attributes of the sub-variables used in the previous studies were different, results contradictory and inconclusive. The study provided evidence to help clear up the conflicting results of earlier studies on corporate governance and corporate value. The current study was anchored on the positivism philosophy, whose aim was to test hypotheses empirically in order to verify or falsify existing theories in this area. The study results add to the existing theories by revealing the relationships between the variables.

The study used secondary data which obtained from the firms' annual reports and financials as well as information from the company's websites. Such are general-purpose reports and any limitations on data reliability therein could affect the obtained results reliability. In addition, a descriptive research design was adopted to clearly explore the study hypotheses or questions. However, the design has a limitation that it cannot determine causality between variables. Although, the study was able to examine the nature and direction of the variables relationships, it failed to show the effects of causality between variables. The above limitations do not dilute the quality of the findings. The study has made far-reaching contributions to the existing bodies of knowledge touching on areas of corporate governance which still has a lot of room for future studies.

The major recommendation for practice which can be actioned by policymakers and managers to make a substantial impact on performance emerges from our key findings that responded to the core question of the research. This is the finding of the positive and significant effect of corporate governance on corporate value - as explained in the key findings - support the suggestion that corporate failures, frauds, corruption, mismanagement, and underperformance seems to spring from the agency cost. This relates to the loss of control, power, and authority by owners to agents as firms expands and become more complex. It is therefore imperative that the management should, as a matter of priority, implement corporate codes of good conduct, corporate governance policies, company laws and other regulatory requirements. They should ensure that the board independence is upheld, adequate board size is in place to ensure optimal performance and management monitoring and resources. The regulators themselves should go above board and always lead by example. They should be firm, fair, impartial and transparent in their dealings, and policy action should always be done by consensus. Regular structured training courses and participation in seminars and workshops for managers should take place to enhance the quality of leadership. In addition, introductory corporate governance training should be mandatory for new board members.

The current study used quantitative measures of Corporate Value. A similar research may be undertaken based on quantitative as well as qualitative indicators of Corporate Value. This would further broaden the scope of the current study. In a broader context, this study examined the link between value of listed firm and corporate governance. More research can examine the association in particular categories, such as nonprofits organizations, state owned organizations, and family businesses. It would thus be valuable to have a better understanding of the roles of corporate governance in different industrial sectors. Such a study would look at the differences and similarities in roles in dissimilar entities and taking into consideration the legal requirements for the organizations. Future researchers need to incorporate other performance measures, both financial and non-financial other than just Tobin Q considered above. A similar study could be conducted in other countries internationally and regionally. This would further confirm the results of current and future studies.

\section{References}

Ali, M. (2018). Impact of Corporate Governance on Firm's Financial Performance: A Comparative Study of Developed and Non Developed Markets. Journal of Business Management and Economic Research, 2(1), 
15-30. https://doi.org/10.29226/TR1001.2018.7

Alqisie, A. (2014). Do corporate governance indicators lead the firm to adopt high/low level of financial leverage? Case of Jordan. Journal of Management Research, 6, 99-113. https://doi.org/10.5296/jmr.v6i3.5622

Anderson, E. A., Becker, O. P., \& Campbell, H. O. (2014). Insight of corporate governance Theories. Journal of Business and Management, 1(1), 52-63. https://doi.org/10.12735/jbm.v1ilp52

Ayako, A., Kungu, G., \& Githui, T. (2015). Determinants of the Performance of Firms Listed At the Nairobi Securities Exchange. Research Journal of Finance and Accounting, 6(12), 1697-1726.

Beck, J. B., \& Wiersema, M. F. (2013). Executive decision-making: Managerial capabilities to the resource portfolio and strategic outcomes. Journal of Leadership \& Organizational Studies, 20, 408-419. https://doi.org/10.1177/1548051812471722

Bloom, N., Bond, S., \& John Van, J. R. (2001). Uncertainty and Investment Dynamics, Stanford University, Centre for Economic Performance and Institute of Fiscal Studies, University of Oxford.

Calomiris, C. W., \& Carlson, M. (2016). Corporate Governance and Risk Management at Unprotected Banks: National Banks in the 1890s. Journal of Financial Economics, 119(3), 512-532. https://doi.org/10.1016/j.jfineco.2016.01.025

Capital Market Authority. (2019). The Kenya financial sector performance analysis report 2018. Financial Sector Regulators Forum, 5.

Carter, S. M., \& Greer, C. R. (2013). Strategic leadership: Values, styles, and Organizational performance. Journal of Leadership \& Organizational Studies, 20, 379-393. https://doi.org/10.1177/1548051812471724

Carty, R., \& Weiss, G. (2012). Does CEO duality affect corporate performance? Evidence from the US Banking crisis. Journal of Financial Regulation and Compliance, 20(1), 26-40. https://doi.org/10.1108/13581981211199407

Central Bank of Kenya. (2019). The Kenya financial sector stability report 2017. Financial Sector Regulators Forum, 9.

Cooper, C. R., \& Schindler, P. S. (2008). Business Research Methods (10th ed.). Boston: McGraw-Hill.

Creswell, J. W. (2013). Research design: Qualitative, quantitative, and mixed methods approaches. Sage publications.

Dominic, O. O., \& Memba, F. (2015). Effect of corporate governance practices on financial performance of public limited companies in Kenya. International Journal of Management and Commerce Innovations, 3(1), 122-132.

Dor, L. A., Naseem, M. A., Rehman, R. U., \& Niazi, G. S. K. (2011). Corporate governance and firm performance: A case study of Pakistan oil and gas companies listed in Karachi stock exchange. European Scientific Journal, 11(2), 103-128.

Eyenubo A. S. (2013). The impact of bigger board size on financial performance for firms: The Nigerian experience. Journal of Research in International Business and Management, 3(3), 85-90.

Gujarati, D. (2003). Basic Econometrics (4th ed., pp. 638-640). New York: McGraw Hill.

Hasan, A., \& Butt, S. A. (2009). Impact of Ownership Structure and Corporate Governance on Capital Structure of Pakistani Listed Companies. International Journal of Business and Management, 4(2), 50-57. https://doi.org/10.5539/ijbm.v4n2p50

Haque, F., \& Arun, T. G. (2016). Corporate governance and financial performance: An emerging economy perspective. Investment Management and Financial Innovations, 13(3-1), 228-236. https://doi.org/10.21511/imfi.13(3-1).2016.09

Holderness, C. G. (2016). Problems Using Aggregate Data to Infer Individual Behavior: Evidence from Law, Finance, and Ownership Concentration. Critical Finance Review, 5(1), 1-40. https://doi.org/10.1561/104.00000028

Jensen, M., \& Meckling, W. (1976). Managerial behavior, agency costs and ownership structure. Journal of Financial Economics, 3, 305-360. https://doi.org/10.1016/0304-405X(76)90026-X

Kiruri, R. M. (2013). The effects of ownership structure on bank profitability in Kenya. European Journal of Management Sciences and Economics, 1(2), 116-127. 
Kothari, (2004). Research Methods: Methods and Techniques. New Delhi: AGE International.

Lekaram, V. (2014). The relationship of corporate governance and financial performance of manufacturing firms listed in the Nairobi securities exchange. Journal of Business and Commerce, 3(12), 30-57.

Lishenga, J. (2012). Corporate governance reaction to declining firm performance: Evidence from NSE. African Journal of Business Management, (1), 24-42.

Mang'unyi, E. E. (2011). Ownership Structure and Corporate Governance and Its Effects on Performance: A Case of Selected Banks in Kenya. International Journal of Business Administration, 2(3), 2-18. https://doi.org/10.5430/ijba.v2n3p2

M'Ithiria, E. N., \& Musyoki, D. (2014). Corporate governance, ownership structure perspective and firm value: theory, and survey of evidence. International Journal of Research in Management \& Business Studies, 27, $1-3$.

Morrison, J. R., \& Jenson, N. J. (2013). The strategic use of corporate board committees. California Management Review, 30(1), 109-125. https://doi.org/10.2307/41165269

Okiro, K. O. (2014). Corporate governance, capital structure, regulatory compliance and performance of firms listed at the East African community securities exchange (Doctoral dissertation, University of Nairobi).

Opiyo, E. (2013). Effects of corporate governance on insider trading A case of listed companies on Nairobi securities exchange. Prime Journal of business administration and Management, 9(5), 49-61.

Peters, G. T., \& Bagshaw, K. B. (2014). Corporate governance mechanisms and financial performance of listed firms in Nigeria: A content analysis. Global Journal of Contemporary Research in Accounting, Auditing and Business Ethics, 1(2),103-128.

Proudfoot, D. (2016). Board Member. Res. Organ. Behav., 34(1), 683-695.

Robbins, H., \& Judge, G. (2017). Impact of corporate governance on the performance of commercial banks in Zimbabwe. Mediterranean Journal of Social Sciences, 5(15), 203-221.

Rose, C. (2017). The relationship between corporate governance characteristics and credit risk exposure in banks: Implications for financial regulation. European Journal of Law and Economics, 43(1), 167-194. https://doi.org/10.1007/s10657-016-9535-2

Sekaran, U., \& Bougie, R. (2009). Research Methods for Business: A Skill Building Approach (5th ed.). London: John Wiley \& Sons Ltd.

Smith, A. (1776). Wealth of Nations (1991 ed., p. 324). Amherst, NY: Prometheus books.

Solomon, M. C., Gerald, M. M., Alala, O. B., Douglass, M., \& Maokomba, O. C. (2013). Capital Structure and Corporate Governance Practices. Evidence from listed non-Financial Firms on Nairobi security exchange. Journal of Business Management. 10(2), 8-16. https://doi.org/10.9790/487X-1020816

Stiglbauer, M. (2011). Impact of Capital and Ownership Structure on Corporate Governance and Performance: Evidence from an insider system. Journal of Problems and Perspective in Management, 9(1), 16-23.

Velte, P. (2017). Do women on board of directors have an impact on corporate governance quality and firm performance? A literature reviews. International Journal of Sustainable Strategic Management, 5(4), 302-346. https://doi.org/10.1504/IJSSM.2017.089125

Vincent, O. O., K'Obonyo, P. O., Ogutu, M., \& Bosire, E. M. (2015). Board composition and financial performance: Empirical analysis of companies listed at the Nairobi securities exchange. International Journal of Economics and Financial Issues, 5(1), 23-43.

Wagana, D., \& Karanja, K. (2015). The influence of corporate governance on corporate performance among manufacturing firms in Kenya: a theoretical model. International Journal of Academic Research in Business and Social Sciences, 5(4), 258-272. https://doi.org/10.6007/IJARBSS/v5-i4/1571

\section{Copyrights}

Copyright for this article is retained by the author(s), with first publication rights granted to the journal.

This is an open-access article distributed under the terms and conditions of the Creative Commons Attribution license (http://creativecommons.org/licenses/by/4.0/). 